\title{
The Survival and Evolution of Human Resources Management Model in Japan
}

\section{——The Explanation of Evolutionary Economics}

\author{
Xiaoming Qiao \\ Journal editorial department, Yunnan normal university, Kunming, \\ Yunnan, 650092
}

\begin{abstract}
Based on the framework of comparative management analysis, this paper analyzes the survival and evolution of human resource management in Japanese enterprises, and finds out that the long-term survival gene is "loyal to the enterprise" and analyzes it through inheritance, mutation and selection mechanism. This paper argues that for a long period of time, Japan 's human resource management will not be fully consistent with the US model, and will retain its characteristics of the Japanese model and continue to evolve.

Keywords: Japanese Human Resource Management Model; Evolutionary Economics; Existence; Evolution

\section{Introduction}

The generation and evolution of the management mode is a historical evolution process. Since the 1980 s, under the influence of the economic globalization, marketization of the economic system and the third revolution of science and technology, all the enterprises, in order to be able to win in the global competition, to adopt more effective management mode, improve the management level, Improve business performance. It also contributed to the world's management model to the higher efficiency of the model reference and transplantation, showing a certain convergence trend. A typical convergence of management
\end{abstract}


models is the convergence of corporate governance models in various countries (Gao Chuang, 2009) [1].

However, existing research has found that although management theory and management practice have been developed all over the world, there is still no sufficient evidence to show that any management model is universally applicable, nor is there any management model in any situation are the strongest competitiveness. In fact, both countries' human resource management model and corporate governance model, although to some extent, show functional convergence, but still far from the formal convergence. Japan, Germany as the representative of the internal control management model to the United States, the United Kingdom as the representative of the outside, as the representative of the United States, the United Kingdom, as the representative of the domestic and foreign enterprises, Control-based management model in their respective countries in the management context to show a strong adaptive efficiency. So how to explain the current national management model that is showing a certain trend of convergence, but also maintain a certain personality characteristics? This paper argues that the Japanese human resource management model provides us with a good research sample. This paper uses the theory of evolutionary economics to construct a theoretical analysis framework of comparative management research, analyzes the persistence and evolution of the Japanese human resource management model, analyzes the causes of the existence of its management model and discusses the future evolution trend. Management mode development path has a certain reference value.

\section{The Theoretical Analysis Framework}

\subsection{Comparative management research into the feasibility of evolutionary economic theory}

Evolutionary Economics, originally derived from biology, is based on the ideas of absorbing and discarding Lamarck's "use and waste" and Darwin's "natural selection and survival of the fittest", etc., and learn from the inheritance of biological evolutionary process , Mutation and selection mechanism, and supplemented by the biological metaphor of the economic system of new things in the generation, imitation, dissemination and the resulting structural changes to study, and gradually formed a new paradigm of economic science (Zhou Huibin, An Weidong, 2014) [2]. Nelson and Winter (1982), Aokihiko (1999, 2001), and Hodgson (2007) have been engaged in the research of this field, and many scholars have paid more and more attention to it in the field of evolutionary economics since the 1980s.

This paper argues that the introduction of evolutionary economics theory into comparative management research is an important breakthrough in the management of the "synchronic" analysis into the "diachronic" analysis. The common problem of the management model is to compare the characteristics of each country's management so as to find out the difference. The problem of 
diachronic analysis is to seek the formation and evolution from the historical process of the development of each country's management mode. The reasons and mechanisms, especially those seemingly "non-optimal" management model is to survive the reason. This research paradigm is of great theoretical value for the study of the causes, the current situation and the future development of the specific national enterprise management model.

\subsection{The comparative management analysis framework from the perspective of evolutionary economics}

In evolution, "gene" refers to both at the micro level to maintain a relatively stable and can achieve intergenerational transmission and has the function of variation of cells, is the basis of biological evolution. The introduction of evolutionary economics into comparative management research will help us discover the "management gene" in the management model. This paper argues that the "management gene" is the decisive (dominant) factor which can make the management mode and the management mechanism both produce the variation (innovation) and maintain the relative stability, and is the core factor in the evolution of the management mode. Manifestation of gene management is the dominant system of enterprise rules, organizational structure, its inherent performance for the enterprise management practices, corporate culture, tacit knowledge and other hidden system. "Management of genes" is a key factor in the survival of the management model, once the "management gene" has undergone a variation, the management model will inevitably evolve.

\section{Japanese human resources management model of the survival and evolution of the theoretical explanation}

The "three major artifacts" (OECD, 1972) [6] are the core elements of the Japanese enterprise human resource management model. The term "employment system", "annual power system" and "enterprise union" "Life-time employment system" refers to a long-term employment system adopted by Japanese enterprises. This system of employment is often aimed at young job-seekers who have just graduated from university. After they have passed the enterprise probation period, they become employees of the employed enterprise. Term employment status, as long as the business does not fall into serious business difficulties, their own no major fault will be able to maintain long-term employment relationship until retirement. The employment of Japanese companies under the employment system of high stability of employees, employers rarely dismiss unilaterally. Even in times of economic recession, when companies are over-man- aged, they are often replaced by pay cuts, rotation, or training. "Year of the work of the system" is the "lifetime employment system" supporting the promotion of the system and employees enter the company, with the length of service, according to age, length of service and education and other factors, from time to time to raise wages and promotions one position. "Trade 
unions within the enterprise" is a trade union organized as a unit, and its existence enables enterprises and employees to form a solid interest community (Wang Mo Fan, 2012) [7].

\subsection{The management of gene implantation}

Japanese human resources management model of the historical origins can be traced back to the earliest Edo era "Feng public" system. During the Edo period, Japanese merchants, for the sake of management and development of the family business, overcome the limitation of the number of family members, and often choose to employ "living in public" to enter the family and participate in management. The purpose of the service is to provide a long-term, stable life and the development of its own business. At the same time, the main family in order to serve the life of the main home, To ensure the business ability and absolute loyalty of the public, often will adopt a certain way of ideological and moral education and business training (Cheng Yongming, 2001) [8]. Therefore, the extensive implementation of the system of public servants in the formation of a simulated blood relationship between the master and servant, this simulated blood relationship effectively complement and expand the traditional feudal family of the father-child relationship, master-slave relationship, the formation of Japanese characteristics "home" "Loyalty" thinking, and effectively promote the business of family business development.

\subsection{The evolution of the human resources management model in the process of industrialization}

During the Meiji Restoration, Japan established the industrialization system in a relatively fast time. In the human resources management mode, most state-owned enterprises borrowed the labor employment model of the western countries in the early stage of the industrial revolution, implemented the system of contracting labor and obtained the most profit through cruel slavery and exploiting workers. . This process of industrialization can be seen as the traditional employment system in Japan by foreign "novelty" of the impact of the reaction. However, the Japanese working class for this brutal employment system for fierce resistance, the outbreak of the "rice riots" and a series of campaigns, and ultimately makes Japanese human resources management model has not transformed into a shortterm model of Western countries. The "mutation" did not change the management system of the Japanese employment system through the selection mechanism, but then the Japanese business owners recognize the importance of the traditional employment system.

\subsection{The evolution of the postwar human resources management model}

After World War II, in the United States "Dodge route" with the support of Japan began post-war reconstruction. For Japanese employees, on the one hand, with the democratization of the Japanese government, the dissolution of the chaebol group, long-standing differences in the status of employees gradually disappeared; 
the other hand, when Japan is undergoing reconstruction to the rapid development of the Stage, the rapid economic development makes the employment demand surge, but this time in Japan because the war consumes a large number of young and middle-aged labor force, skilled skilled workers are scarce. Therefore, Japanese companies hope to establish a long-term employment system, access to stable labor force to protect the normal operation and development of enterprises. Therefore, the life-time employment system began to be fixed as a practice in Japanese society (Aoki Masahiko, Okuno Masahiro, 1999) [9]. In the 1970s, with the Japanese products in the world to show strong competitiveness, with the lifelong employment system as the core, supplemented by the annual power sequence system and trade unions within the "three artifact" is also worldwide attention, The Characteristics of the Japanese Human Resource Management Model Differentiated by American Management.

Zaibatsu enterprises "loyal to the enterprise" gene is more loyal to the family of chaebol, with a more strong feudal family thinking. The dissolution of the post-war zaibatsu enterprises, democratization reform, a large number of demand with the "novelty" led to the Japanese human resources management model showing a new direction of evolution, "three artifact" established, making Japanese enterprises human resource management model.

Table 1 Japanese human resources management model evolution path

\begin{tabular}{|c|c|c|c|c|}
\hline \multicolumn{2}{|r|}{ era } & $\begin{array}{l}\text { Mutation mechanism } \\
\text { (novel) }\end{array}$ & $\begin{array}{l}\text { Genetic mechanism } \\
\text { (Regulatory gene) }\end{array}$ & $\begin{array}{l}\text { Selection mechanism } \\
\text { (Evolution of the lifetime } \\
\text { employment system) }\end{array}$ \\
\hline \multicolumn{2}{|c|}{ The Edo period } & $\begin{array}{c}\text { "Home" concept, } \\
\text { Bushido, Confucianism }\end{array}$ & Loyal to the home & Public system \\
\hline \multicolumn{2}{|c|}{ Meiji era } & $\begin{array}{l}\text { Meiji Restoration, } \\
\text { Industrialization, } \\
\text { Contract System }\end{array}$ & Interruption & Interruption \\
\hline \multicolumn{2}{|c|}{ Taisho era } & $\begin{array}{c}\text { Enterprise privatization, } \\
\text { the formation of } \\
\text { zaibatsu }\end{array}$ & $\begin{array}{l}\text { Loyal to the enterprise } \\
\text { (formation) }\end{array}$ & $\begin{array}{l}\text { Life-long employment, on the } \\
\text { capital upgrade, bonus system }\end{array}$ \\
\hline $\begin{array}{c}\text { Showa } \\
\text { era }\end{array}$ & $\begin{array}{l}\text { The } 20 \text { th century, } \\
50-80 \text { years }\end{array}$ & $\begin{array}{c}\text { Post - war economic } \\
\text { development } \\
\text { Human Resource Needs } \\
\text { Democratic } \\
\text { consciousness }\end{array}$ & $\begin{array}{l}\text { Loyal to the enterprise } \\
\text { (enhanced) }\end{array}$ & $\begin{array}{c}\text { Lifetime employment system, } \\
\text { annual power sequence system, } \\
\text { Trade unions within the } \\
\text { enterprise }\end{array}$ \\
\hline $\begin{array}{c}\text { Heisei } \\
\text { era }\end{array}$ & $\begin{array}{l}90 \text { years after the } \\
20 \text { th century }\end{array}$ & $\begin{array}{l}\text { economic recession } \\
\text { Knowledge economy } \\
\text { Individualized } \\
\text { consciousness }\end{array}$ & $\begin{array}{l}\text { Loyal to the enterprise } \\
\text { (weakening) }\end{array}$ & $\begin{array}{l}\text { Internal and external } \\
\text { recruitment, performance pay, } \\
\text { Early retirement }\end{array}$ \\
\hline
\end{tabular}




\section{Conclusion}

Based on the theory of evolutionary economics, this paper constructs an analytical framework of comparative management, and makes a theoretical explanation of the survival and evolution of human resource management model in Japan. This paper argues that the initial "genes" of the evolution of human resource management model in Japan originated from the "loyalty to the main family" concept in the Edo period. Since the Meiji Restoration, the management situation of Japanese enterprises has changed a lot. Human resource management model is affected by the inheritance mechanism, the mutation mechanism and the selection mechanism, which makes the management genes evolve from "loyal to the home" to "loyal to the enterprise". After World War II, with the economic recovery and development of Japan, the Japanese characteristics of human resources management model was formally established, "loyal to the enterprise" management gene has been further strengthened. Since the 1990s, Japanese human resource management model has taken a series of adjustment and reform in order to adapt to the new situation inside and outside the enterprise, showing the tendency of functional convergence to the British and American human resources management model, but the "loyalty" Existence, Japanese human resources management model will continue in the long term to survive.

\section{References}

[1] Gao Chuang. Corporate governance: principles and cutting-edge issues. Beijing: Economic Management Press, pp. 15-18, 2009.

[2] Zhou Huibin, An Weidong. Comparative management analysis paradigm: a system and evolution perspective . Journal of Shandong Institute of Business, 4(2), pp. 45-46, 2014.

[3] Cai Lixin. The Evolution Analysis Method of Comparative Management Category, Significance and Application Path .Comparison Management, 4(6), pp. 1(2), pp. 23-24, 2010.

[4] Lv Li. Comparative Management: Synchronic and Diachronic, Description and Comprehension . Comparative Management, 1(3), pp. 28-32, 2011.

[5] [US] Nelson, [US] Winter. Evolutionary theory of economic change [M]. Hu Shikai translation. Beijing: Commercial Press, pp. 15-18, 1997.

[6] OECD, Ministry of Labor, OECD Report on Labor [M]. Tokyo: Japan Labor Association, pp. 7-11, 1992.

[7] Wang Mofan. The Historical Change of Japanese Lifelong Employment System. Journal of Capital University of Economics and Business, 4(2), pp. 34$35,2012$.

[8] Cheng Yongming. Japanese life-long employment system in the past, present and future trends, Tianjin: Tianjin People's Publishing House, pp. 54-55, 2001.

[9] [Japan] Aoki Chang Yan, [Japan] Okuno Masahiro. Comparative analysis of economic system. Wei Jia. Ning translation. Beijing: China Development Press, pp. 11-13, 1999. 